\title{
PENELEH, A SECOND LIFE TO AN OLD DUTCH CEMETERY
}

\author{
Hans Versnel \\ ICOMOS NL, The Netherlands \\ e-mail: jversnel@inter.nl.net
}

\begin{abstract}
To a certain extent there is a second life to the former Dutch cemetery Peneleh in the centre of the city of Surabaya, Indonesia. The present days obsolete condition can be revitalised through the needed expansion of the pasar; a recreational area to the residents of the densely populated surrounding kampung; a reuse of the former caretaker house at the entrance, which is now a Puskesmas, community health centre, and part of the graveyard can revive as monumental location to show the history.These strong points to revitalise the area are effective through a close connection with residents, planners and authorities, which can be put in a participatory process. Dead or alive, potentially the Peneleh area is worth to be redeveloped into an attractive residential part of Surabaya. A heritage worth to visit by domestic and foreign visitors.
\end{abstract}

Keywords: revitalize, Peneleh, Dutch cemetery

\begin{abstract}
ABSTRAK
Pada perkembangan tertentu ada kehidupan kedua bagi eks pemakaman Belanda di Peneleh di tengah kota Surabaya, Indonesia. Saat ini kondisi tersebut dapat direvitalisai melalui kebutuhan ekspansi pasar; sebuah area rekreasi bagi penduduk yang memiliki populasi padat di sekitar kampung; penggunaan kembali rumah jaga masa lalu di pintu masuk yang sekarang menjadi puskesmas (pusat kesehatan masyarakat) dan bagian pemakaman dapat dibangkitkan kembali sebagai lokasi monumental yang menunjukkan sejarah. Poin-poin ini untuk merevitalisasi kawasan yang efektif melalui hubungan dekat dengan penduduk, perencana dan pemilik yang dapat dilibatkan dalam proses partisipatori. Hidup atau mati, Peneleh memiliki potensi yang berharga untuk dikembangkan menjadi bagian permukiman Surabaya. Sebuah warisan budaya yang berharga untuk dikunjungi oleh penduduk lokal dan pengunjung asing.
\end{abstract}

Kata kunci: revitalisasi, Peneleh, pemakaman Belanda 


\section{INTRODUCTION}

In the very centre of the build-up area of Surabaya, the second largest city of Indonesia, the Makam Belanda, Dutch graveyard, is located amidst a densely populated kampung Peneleh. While this cemetery was established in 1847 since 1917 it was already out of operation after it was considered fully occupied. From that time new graves were not added but burials in existing family graves were still possible. Originally the Peneleh graveyard was situated outside the old city centre as the government bought new land in the swampy area. The condition was not favourable for a cemetery but before it opened the selected plot was raised with sand and drained from superfluous water. A special road was constructed to connect the graveyard with the city and a bridge was build. This Kerkhoflaan (Graveyard road) is now the Jalan Makam Peneleh and the bridge is still there. Soon after the graveyard was established at the location the kampung Peneleh gradually surrounded the area by moving in the swampy grounds around it. The signboard of Peneleh Graveyard is shown in Figure 1.

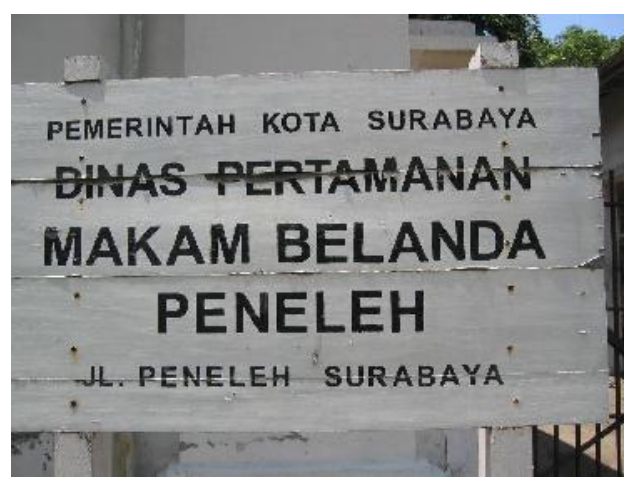

Figure 1. Signboard at Main Entrance

Surabaya was a rather fast growing city in the field of industrial and related harbour development, which brings an economic development requiring anever growing population. The hinterland with its plantations enhanced also the trade function through the harbour. While the population growth was in urgent need of land to develop housing, there was also a need for graveyards. Through the city you can find old graveyards and some of them havealready been cleared. The Peneleh graveyard replaced the former one atKrembangan in the old city centre and after Peneleh the KembangKuningcemetery came into operation.

\section{RESULTS AND DISCUSSION}

\section{Remarkable Kampung}

Today's kampung Peneleh is a somewhat hidden and quiet residential area located in between the Kali Mas and Kali Pigirian and surrounded by busy and noisy traffic. 
As far as it is observed the kampung Peneleh is a vital community with a pasar and cottage industry activities in a rather well kept environment. Living conditions seem rather well, compared to other kampung in the city. A heterogeneous community in which family ties are rather strong and helpful.

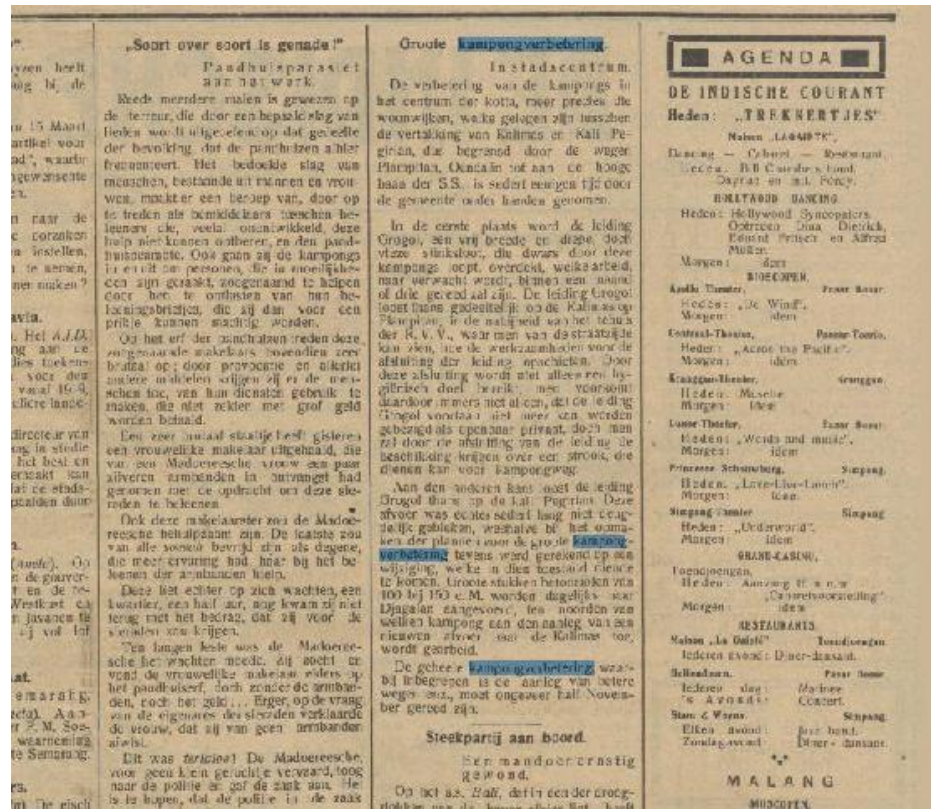

Figure 2. Newspaper De Indische Courant March 18, 1930 with the Announcement of the Proposed Kampung Verbetering

But living conditions have not always been as good as it is now. During Dutch rule in the 1930's it was necessary to improve the kampung condition. The then Dutch newspaper De Indische Courant of March 18, 1930 wrote about the kampung verbetering, kampung improvement, aiming to cover the Grogol ditch which was awfully stinking by using it to discharge filth of residents living in that area (Figure 2). Another aspect of these improvements in colonial times was to restore rooilijnen, building lines, which were neglected due to wild occupation of the area. This was always controversial for the improvements meant by the colonial government and it still is a conflict if participation is not part of the decision making process.

The kampung Peneleh has a remarkable history. Sukarno, the first president of Indonesia, was born in Pandean Peneleh IV nr. 40. A plaquette at the entrance of the street indicates the house he was born. Sometime later he moved with his parents for Blitar where his father was stationed for a new function. Sukarno came back to Peneleh to study the Hogere Burgerschool (HBS), secondary school, and during these years he stayed in de kos, lodging, at the house of Cokroaminoto, the well known nationalist, in Peneleh VII. The well-kept house is remarkable item in the kampung. 
From an architectural point of view many building structures in Peneleh can be classified as kampung art deco, adding to the special features of the kampung. Still there is a great variety in architectural style culminating in the eclectic style of Ons Hoekje, our little corner, near the entrance of the cemetery showing the Dutch relation.

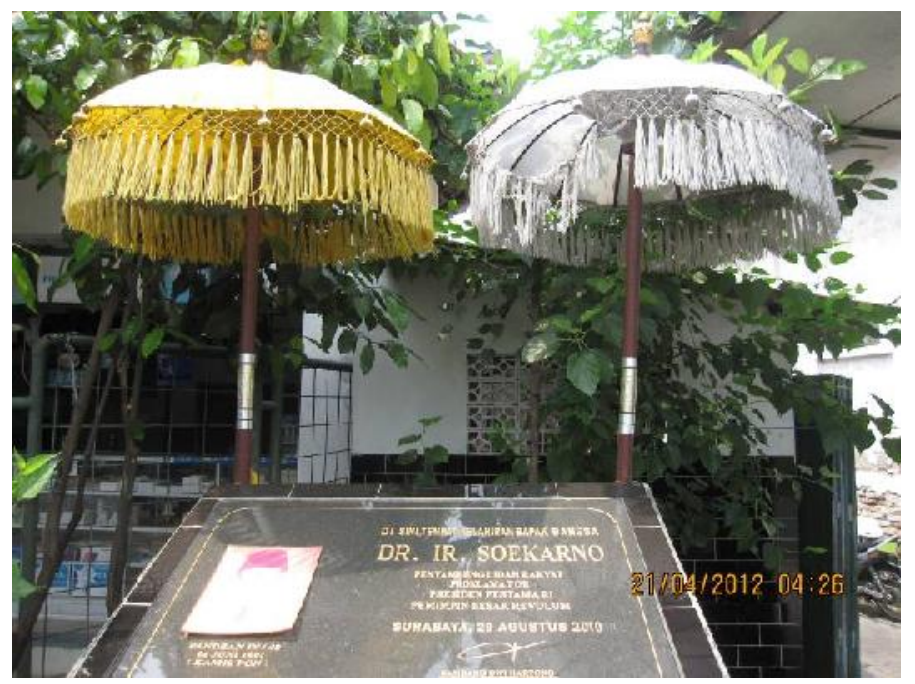

Figure 3. Plaquette Indicating the House Soekarno was Born

\section{The Desolate Graveyard}

Today the cemetery with its 4,5 hectares is in a desolate and ruined state but showing a special attractiveness from heritage point of view. It must be a burden to the city administration of Surabaya looking for a new future of the area, while there is hardly a connection between de surrounding kampung and the cemetery. To residents the cemetery has no social or economic relation and they don't see the cemetery as 'theirs'. The cemetery is used as thoroughfare as the footprint shows and wild occupations took place during many years.

So the question is how to match the demand for redevelopment with the heritage of a long-lasting relationship.

From the Indonesian side with the Pemkot Surabaya and the Institut Teknologi Sepuluh November Surabaya (ITS) and from the Dutch side the Cultural Heritage Agency (RCE) together held the Peneleh Conservation and Development Workshop in October 2011. The overall conclusion was that the Peneleh cemetery could be considered as an asset for future development, due to its historical and spatial features it can contribute to improve the living conditions of the surrounding residential areas. 


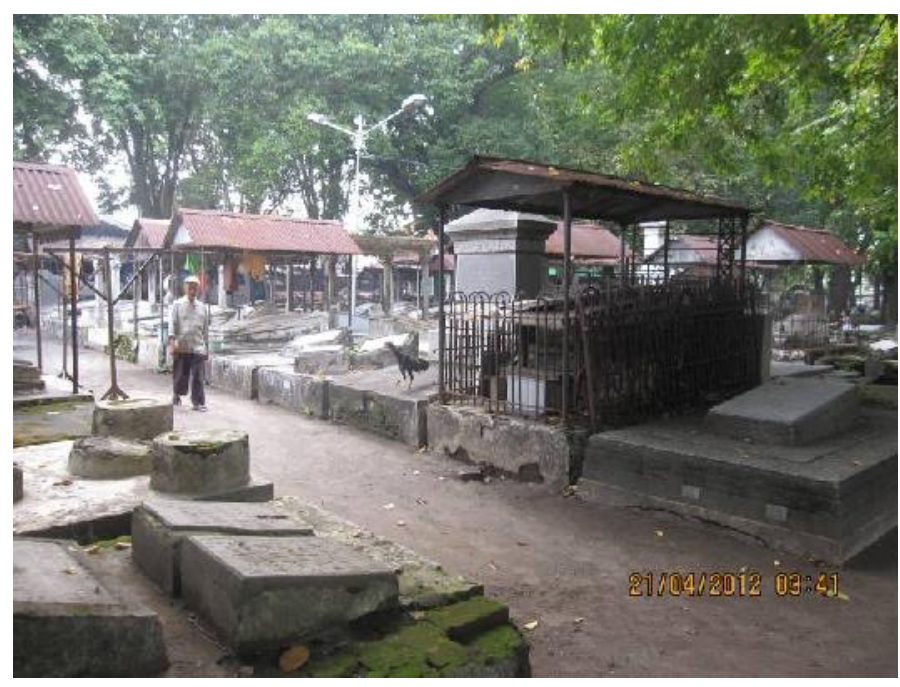

Figure 4. View on the Desolate Condition of the Graveyard and the Greenery of Big Trees

\section{Spatial Features}

There is a high potential on spatial features of the Peneleh cemetery, which can be translated into a vision for future development. First there is the recreational aspect for which a park can be the main feature providing open space to the residents of the surrounding kampung and deliver walking routes through the area as there are already a few so called elephant paths. Partly these are already the connections with the existing pasar, which as a second feature can be expanded to provide more space and more traders under improved conditions. Anyway, it is important to maintain part of the cemetery to re-use the remaining historical elements as well as to preserve individual graves. This includes also the re-use of the former caretakers house at the entrance and nowadays housing a Puskesmas. Of great value are the existing trees, which have to be protected and integrated in the park including the above-mentioned features.

\section{Requirements}

The future development of the site is subordinate to Surabaya's current master plan, indicating the Peneleh cemetery as a green area. Therefore a historical analysis is required by a detailed investigation into the graves and the deceased including an up-to-date and complete documentation and registration of the gravesites. To further the development of the area an implementation plan should be drawn. Though it is mentioned as a Makam Belanda, the main responsibility lies at Pemkot as the owners of the land. But planning and implementation can only be effective if a participatory process with surrounding kampung residents is undertaken. This seems not that innovative but to implement such a process into a graveyard redevelopment could be amazing while it could support a beneficial development to the residents. 


\section{CONCLUSIONS}

Public awareness should be raised at the historical significance and future potentials to a second life for the Peneleh graveyard. Re-use of historical elements and structures can only be effective if residents and public are aware of the historical significance of this site. Re-use is acceptable if the public feels that it can benefit of this by means of commercial activities in trade, food stalls, adequate traffic and others. The booming economy of Indonesia could provide labour opportunities in a challenging revitalisation of the Peneleh cemetery as an attractive historical location for tourist, domestic as well as foreign.

\section{REFERENCES}

Peneleh Conservation and Development Workshop (2011) Peneleh's second life, Future Perspectives of an Historical Cemetery, report Rijksdienstvoor het Culturele Erfgoed. 